CIHM Microfiche Series (Monographs)
ICMH

Collection de microfiches (monographies)

Canadian Institute for Historical Microreproductions / Institut canadien de microreproductions historiques
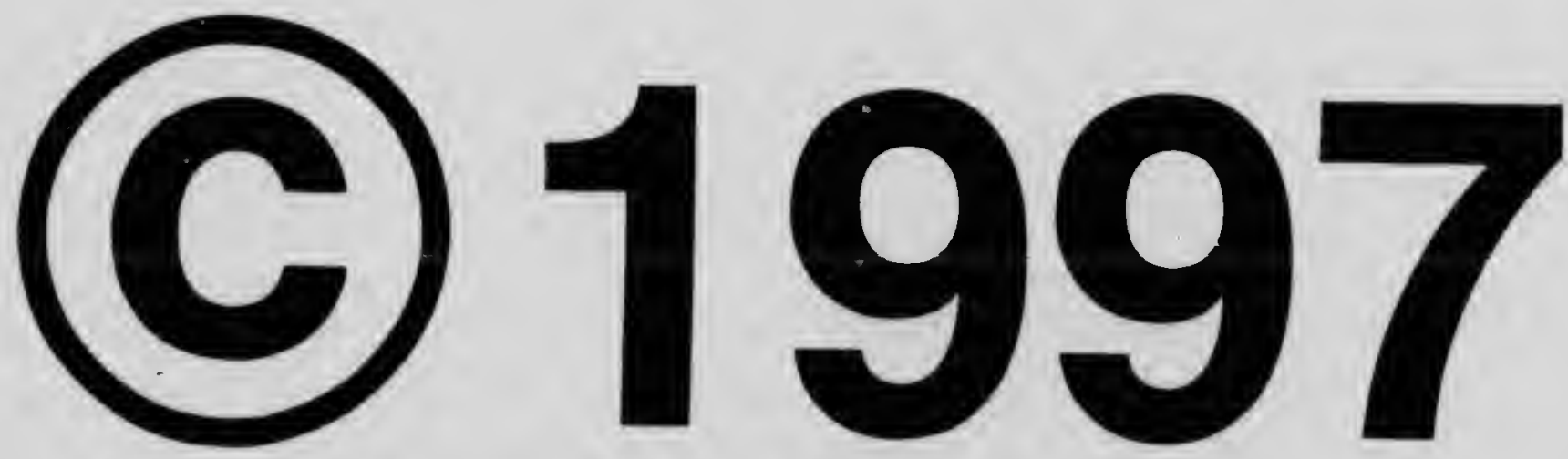


\section{Technical and Bibliographic Notes / Notes techniques et bibliographiques}

The Institute has attempted to obtain the best original copy available for filming. Features of this copy which may be bibliographically unique, which may after any of the images in ti?e reproduction, or which may slgniflcantly change the usual method of filming are checked below.

\section{$\checkmark$ Coloured covers I \\ Couverture de couleur}

\section{Covers damaged /}

Couverture endommagée

Covers restored and/or laminated /

Couverture restaurée evou pelliculée

Cover title missing / Le titre de couverture manque

Coloured maps / Cartes géographiques en couleur

Coloured ink (i.e. other than blue or black) /

Encre de couleur (i.e. autre que bleue ou noire)

Coloured plates and/or illustrations /

Planches eVou illustrations en couleur

Bound with other material /

Relié avec d'autres documents

Only edition available /

Seule édition disponible

Tight binding may cause shadows or distortion along interior margin / La reliure serrée peut causer de l'ombre ou de la distorsion le long de la marge intérieure.

Blank leaves added during restorations may appear within the text. Whenever possible, these have been omitted from filming / II se peut que certaines pages blanches ajoutées lors d'une restauration apparaissent dans le texte, mais, lorsque cela était possible, ces pages n'ont pas été filmées.

Additional comments /

Commentaires suipplémentaires:
L'institut a mlcrofilmé le meilleur exemplaire qu'il lul a été possible de se procurer. Les détails de cet exemplaire qui sont peut-être unlques du point de vue bibllographique, qui peuvent modifier une image reproduite, ou qui peuvent exiger une modiflcation dans la métho. de normale de filmage sont indiqués ci-dessous.

\section{Coloured pages / Pages de couleur}

Pages damaged / Pages endommagées

Pages restored and/or laminated /

Pages restaurées etlou pelliculées

Pages discoloured, stained or foxed /

Pages décolorées, tachetées ou piquées

Pages detached / Pages détachées

\section{Showthrough / Transparence}

Quality of print varies /

Qualité inégale de l'impression

Includes supplementary material /

Comprend du matériel supplémentaire

Pages wholly or partially obscured by errata slips, tissues, etc., have been refilmed to ensure the best possible image / Les pages totalement ou paitiellement obscurcies par un feuillet d'errata, une peiure, etc., ont été filmées à nouveau de façon à obtenir la meilleure image possible.

Opposing pages with varying colouration or discolourations are filmed twice to ensure the best possible image / Les pages s'opposant ayant des colorations variables ou des décolorations sont filmées deux fois atin d'obtenir la meilleure image possible.

This item is filmed at the reduction ratio checked below / Ce document est filmó au taux de réduction indiqué ci-dessous.

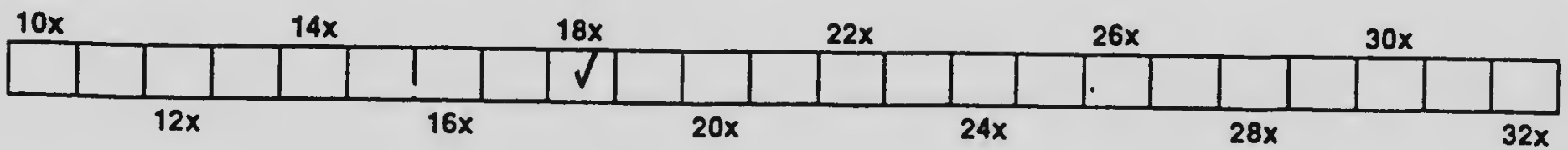


The copy filmed here has been reproducad thenks to the genorosity of:

\section{National Libraxy of Canada}

Thn imeges eppeoping hare ere the best quolity possible considering the condition and logibillty of the originel copy and in keoping with the tilming contrace spociticotiona.

Originai copies in printed peper covere ere filmed boornning with the tront cover und ending on the last pege with a printed or illuetroted impres. sion, or the beck cover when eppropriate. All ornor original copies are filmed beginning on the firse pege with a printed or illustrated impres. sion, and ending on the lust puge with a printed or illustrated impression.

The lest recordud frame on each microfiche sholl coneain the symboi $\longrightarrow$ Imeaning "CON. TiNUED") or the symboi $\nabla$ (meoning "ENO"). wh.shover epplies.

Mops. platas. chsres. otc., moy be tilmad ot different reduction rstios. Those 100 ierge to be entireiy inciuded in one axposure are filmod beginning in the upper lott hand corner. loft to right and top to bottom. as many frsmos as required. The following diograms illustrete the mothod:
Lexemplaire filmo tus reproduit grace th odndrosite do:

Blbllothogue nationale du canada

Les imeges suiventes ont bts reproduites evec le pius grand soin, compre renu de le conditson of de la narrete de l'exempleire fiime, at on conformite evee los conditions du contret de filmoge.

Les exemplaires originoux dont lo couveriure on papier est imprimte sont filmes an commancent pur lo premiar plat at an torminant soit per la dernitre peoe qui comporte une empreonte d'impression ou d'illustrstion, soir por lo second plos, selon le ces. Tous las outras sxempiarres originaux sont tilmbe en commencant por lo pramiore page qui comporte une emprainte dimprassion ou d'illustrotion ot en terminant par lo derniere poge qui comporta une rolle omprointe.

Un des symboies suivents apperaitrs sup le dernidre imoge de cheque microtiche. solon le cos: is srmbole - signifie "A SUIVRE". is symbole $\nabla$ signifie "Fin".

Lss corres. planches, tobleaux, atc.. pauvant otrs tiimbs des raux de rduction differents. Lorsque lo documant ast trop grand pour ótre reproduir en un soui clichb. il est fiime partur de l'angle suptrieur gouche. de gauche d droite. ot de hout an bes. on prenent la nombrs d'imogas ndcessaire. Los diegremmes suivents illuetront is mothode.

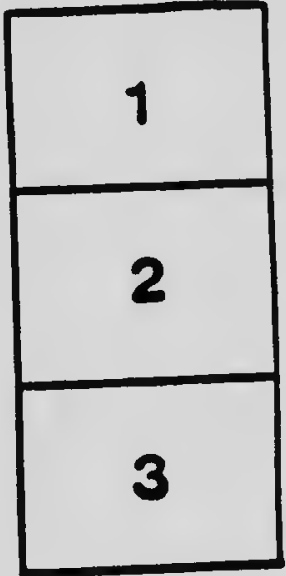

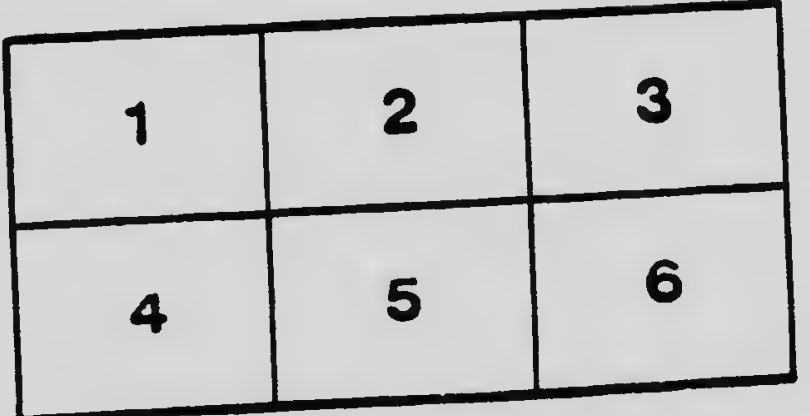




\section{MICROCOPY RESOLUTION TEST CMART}

(ANSI and ISO TEST CHART NO. 2)
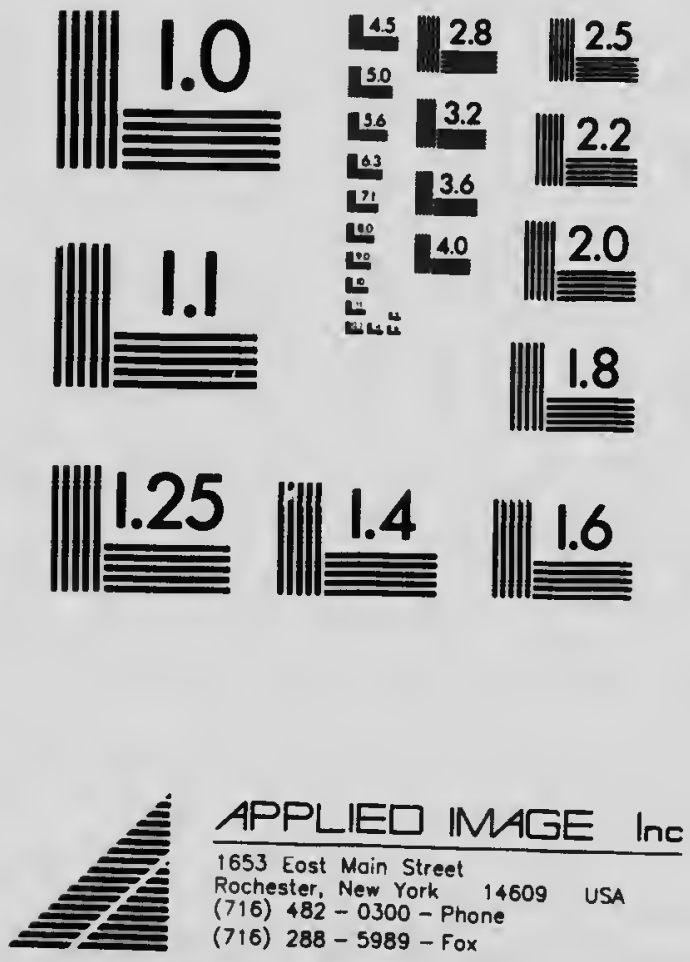
$\hat{i}$ 


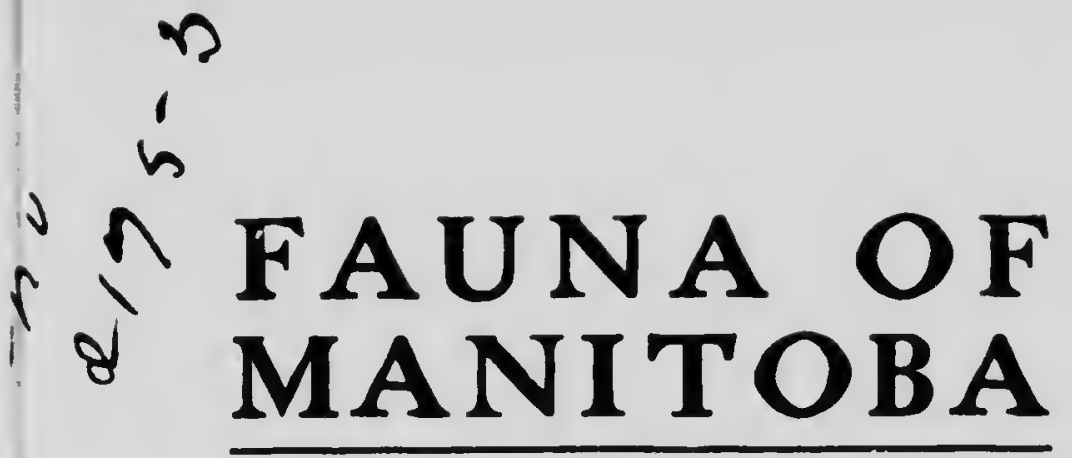

By

ERNEST THOMPSON SETON

As appeared in Biltish Association Handbook, Winnipeg, 1909 


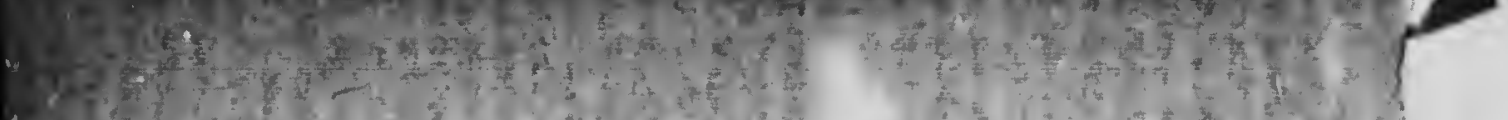

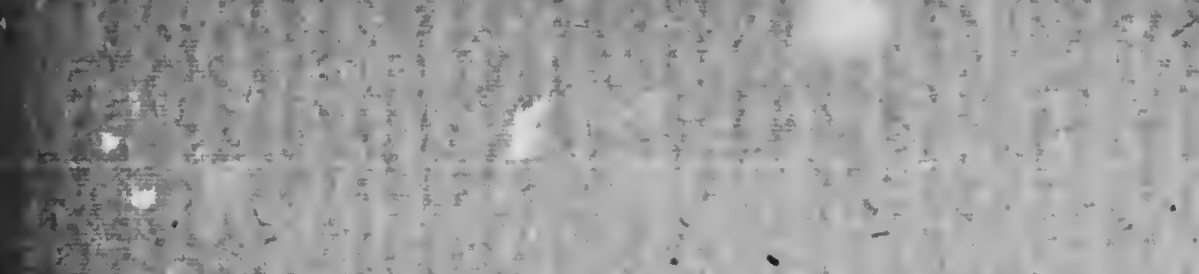

$\checkmark$

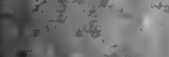

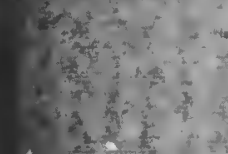

$3 \frac{x}{3}$

(n)

7) $1 y^{2}+t^{3}$

(

$5^{2}=$

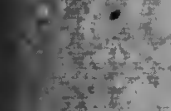

axt

$-4,8$
+35

c.

$2 x-\frac{2}{2}$

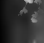

$t^{2} x^{2}$

$-x+2$

I. $\frac{1}{2}$

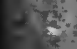

tent

$3 y=$

$x^{2}-x^{2}-x^{2}$

$x+y=1$

$-45 y^{3}$

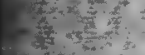

$x+y, y$

wet

$\frac{31}{2} x^{2}$

$4 x+y$

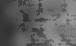

$\frac{3}{4}+\frac{1}{2}=1$ 




\title{
FAUNA OF MANITOBA
}

\author{
(Maminals and Birds) \\ BY ERNEST THOMPSON SETON, \\ Naturalist to the Govemment of Manitoba.
}

M

ANITOBA is 268 by 252 miles, or 74,448 square miles. It lies wholly within the great wheat belt of the north-west, but faunally speaking it is in the Temperate Region, partly in the Canadian Lifezone and partly in the Alleghanian portion of the Transition Zone. A line drawn from the south-east corner to the north-west corner would nearly demark these two zones. The Canadian area, north-east of this line, is nearly all foresterl. The prevailing trees being black spruce, white spruce and jack pine. The Alleghanian area, south-west of the line, comprises the prairies of the Provinca, and a considerable region of aspen forest.

Riding, Duck and Porcupine Mountains may be considerec Canadian islands in the Alleghanian region.

\section{MAMMALS OF MANITOBA}

(The nomenclature is that of the United States Biological Survey.)

1. Wapiti or Canadian Elk, Cervus canaden: is Erxleben. Formerly found in all the Alleghanian region of the Province. Reduced to a few stragglers twenty years ago, but since then, owing to good game laws, they have speedily increased and now furnish a regular supply of game. The estimaterl number of Wapiti in Man: oba to-day is 5,000 .

2. Northern White-tailed Deer, Odocoileus virginiunus borealis Miller. Unknown in the Province until 
about thirty years ayo. since en it has greatly increased, follow:.ng the settlers; now found wherever there are settlements arljoining woorls.

3. Mule-deer, Odocvileus hemionus (Rafinesque). liormerly abundant in all the Alleghanian Region; greatly reduced some twenty years ago, but now once more abundant in its proper regiun, wherever there is eover combined with broken ground

4. Moose, Alces americanus Jardine. Abundant in all the forested area of the l'rovinee; apparently in no danger of extinction, since reasonable game laws have come in force. Several thousand are killed each ear in the Province. The estimated total head of Moose within our limits is between 20,000 and 30,500 .

i. Woodland Caribou, Rangifer caribou (Gmelin). Found only in the Canadian region, and nowhere common. It is more or less migratory, eoming fifty to one hundred miles farther south for the winter.

6. Prong-horned Antelope, Antilocapra americana (Ord). Formerly found in all the prairies of the south-west. Recurded once or twice in early days very near Winnipeg; last seen on the Souris about 1881. Now extinet in the Province.

7. American Bison or Buffalo, Bison bison (Linnaeus). Formerly found in great abundance on all the prairies of Manitoba. Last seen wild near Winnipeg in 1819. Lrist great wii ${ }_{3:}^{-1}$ on the Souris 1867; the last wild individual on the Souris 1883.

s. Red-squirrel, Scruus hudsonicus Erxleben. Abundant in every timbered portion of Manituba, and active the year round.

9. Eastern Chipmunk, Tamias striatus griseus Mearns. Abundant in the woods of the south-eastern part of 
the country and westward to Portage la Prairic. Hibernating during the winter.

11). Little Chipmunk, Futamias qumlrivillatus negleitus (Allen;. Of geveral distribution in the southern half of the I'rovince wherever there is timber and dry land. Exceedingly abu lant, living like the preceling. Hibernating all inter.

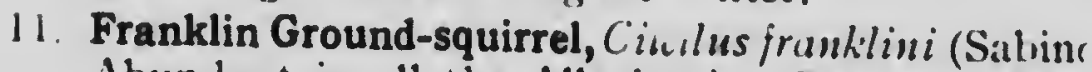
Abundart in all the Alleghanian Region of $M a$. toba wherever there is woodland alternating wius open sunny places. Like the rest of the Groundsquirrels $t^{t}$ s $q$ quite omnivorous, but stores up only vegetable substances for bad weather supplies. It hibernates for six months of each year.

12. Richardson Ground-squirrel, Citellus richardsoni (Sabine). Exccedingly abuudant on all the dry rolling prairies west of Pembina Mountain and south of Lake Manitoba extending up a little way in the Gilbert Plains country and the Upper Assiniboine. Hibernating all winter.

1:. Striped Ground-squirre Citellus rilecemlineatus (Mitchill). Common on all the, iries of Manitoba, but much less so thar in prinitive times. Its burrow is so easily disturbe $i$ is the plow that cultivation is bound to ?xtermin'ia it. It hibernates for six months of $c$ is year.

11. Woodchuck, Murmota monax canalensis (Erxleben). Found in all parts of the Province where there is dry wools, but nowhere abundant. More common probably about Duck Mount,ain tha elsewhere. It hibernates for four or five months of the year.

1i). Canadian Flying-squirrel, Sciuropterus subriuus (Shaw). Common in all parts of the country. Some years very abundant, but rarely seen on account of its nocturnal habits It is active all winter. 
16. Canada Beaver, Castor canadensis Kuhl. Formerly very abundant in all parts of Manitoba. Reduced to very few some years ago, but owing to fostering laws it has since increased and may once more become plentiful.

17. Common House-mouse, Mits musculus Linnacus. Introduced with settlers in 1882; now abundant in all towns.

18. Grasshopper-mouse, Onychomys leucogaster (Wied). Found only on the dry prairies at the extreme south.western corner of the Province.

19. Arctic Deermouse, Peromyscus maniculatus arcticus (Mearns). Abundant throughout the country wherever there is woods; especially fond of frequenting barns and outbuildings that are near the edge of the forest. Closely related to it, probably mere races, are the Prairie Deermousc (bairdi) found in the prairie regions and the plains, or $\mathrm{Ne}$ braska Deermouse (nebrascensis) found in the Souris country. True maniculatus should be found in westerri Manitoba.

20. Red-backed Vole, Evotoinys gapperi (Vigors). Cienerally distributed throughout the Province, though nowhere abundant. It appears in two races, the bright colored, large prairie race (loringi) and the small dark race of the Canadian woods (gapperi).

21. Drummond Vole, Microtus peninsylvanicus drummondi (Audubon and Bachman). Abundant in all sedgy regions of the Province. A harmless species when not in excessive numbers: confining itself to lowlands overgrown with tall giass.

22. Little Vole, Microtus minor (Merriam). Generally distributed in the solith-west or Alleghanian region, but nowhere very abundant. 
23. Muskrat, Fiber zibethicus (I.innaeu.s). Found in great numbers wherever there is water throughout the Province. This animal is an important fur-bearer. Two million of its skins are shipped to London every year by the Hudson's Bay Company, representing of course the entire north-west. It lives in the water, and is rarely seen away from it except when forced to migrate.

2.). Northern Bog-lemming, Synaptomy's borealis (Richardson). Never actually taken in the Province, but recorded from surrounding localities which justify its inclusion. It is abundant in the far north, but not elsewhere common.

2). Gray Pocket-gopher, Thoinomys tulpoiles (Richardson). Abundant on the high, dry prairies of Manitoba, but not extending very far into the woods. It is commonly called Mole by the residents,as it forced up mounds of earth in the fashion of the Mole. It is, however, a herbivorous rodent.

26. Jumping-mouse, Zapus hudsonius (Zimmermann). This extraordinary creature, famous for its long tail and its jumping habits, is found throughout Manitoba, except on the bare prairies. It appears in two forms. The typical Hudsonian, found in the Canadian forest, and the prairic forn (campestris), a bright colored race peculiar to the woodland edges in the prairie portions of the south-west.

27. Canada Porcupine, Erethizon dorsatum (Linnacus). Generally distributed in the Canarlian area of Manitoba, but nowhere abundant. Its quills were formerly the favorite materia! for embroidery among the Indians, but in recent times the squaws liave uscerl glass bearls in preference, so that the art is dying olit. 
28. Snowsibe-hare or White-rabbit, Lepus arinericanus phaeonotus Allen. Found in all parts of Manitoba wherever there is cover. In summer it is brown, in winter pure white. In Turtle Mountain it is represented by the race bishopi, distinguished by its short ears and pale color. The prevailing form in Manitoba is the dusky backed race (pliaeonotus). This hare has long been noted for the excessive fluctuation of its numbers in cycles of seven to ten years. One hundred or more may be seen every day when its numbers are at its height, but usually the plagus breaks out at this time and speedily reduces the Snowshoe population to near zero.

29. Prairie-hare, Lepus campestris Bachman. Formerly found only in the extreme south-west of the Province, and exceedingly rare; now abundant in all the prairie regions, especially in the vicinity of cultivated fields.

30. Canada Lynx, Lynx canadensis Kerr. Found in all the wooded parts of the Province, but varying greatly in numbers on different years.

31. Kit-fox or Swift, Vulpes velox (Say). Formerly common on the high dry prairie of the south-west; now exterminated within o': limits.

32. Royal Fox, Vulpes regalis serriam. Common on the prairies of the province; probably replaced in the woods by the form called fulvus. Less numerous than formerly.

33. Gray-wolf or Buffalo-wolf, Cinis occidentali: Richardson. Generally distributed, but nowhere common.

34. Prairie-wolf or Coyote, Canis latrans Say. Abundant in all the south-western half of Manitoba; probably as numerous now as in th days before settlement. 
35. Canada Otter, Lutra canadensis (Schreber). Found all along the rivers, but exceedingly rare now.

36. Bonaparte Weasel, Putorius cicognanii (Bonaparte). Common in most parts of the Province, but varying greatiy in numbers on different years.

37. Least Weasel, Putorius rixosus Bangs. Nowhere numerous, but ranging over the whole Province. This is the smallest known beast of prey.

38. Long-tailed Weasel, Putorius longicauda (Bonaparte). Abundant in all the prairie region of Manitoba, etc.

39. Mink, Putorius vison (Schreber). Abundant throughout the Province wherever there is water and swamp.

40. Spruce Marten, Mustela amerirana abieticola Preble. Found only in the coniferous forest, and rare there.

41. Pekan or Fisher, Mustela pennanti Erxleben. Found only in the coniferous forest, and rare.

42. Wolverene, Gulo luscus (Linnacus). Rare everywhere, but found in most of the heavily timbered parts of North-easte $n$ Manitoba.

43. Prairie Skunk, Mephitis hudsonica Richardson. This large Skunk is abundant, especially in the halfwooded region.

44. Common Badger, Taxidca taxus (Schreber). Common in all prairie region, but not found in the woods; it is less common than before settlement.

45. Raccoon, Procyon lotor (Linnacus). Very rare and confined to the south-western part of the Province, along rivers whose banks are heavily wooded.

4i. Grizzly-bear, Ursus horribilis Ord. Now extinct in Manitoba, for perhaps 100 years. The records 
show that at one time there were Grizzlies in all the l'embina Hills, Brandon Hills and Turtle Mountain regions.

47. Black-bear, Ursus americanus Pallas. Quitc conmon yet in all parts of Manitoba where there is cover. Both black and brown phases occur in the same litter.

48. Cooper Shrew, Sorex personatus I. Geoffroy St. Hilaire. Generally distributed, and very aburdant in some seasons.

4!). Richardson Shrew, Sorex richardsoni Bachman. Apparently of general distribution, but not common I have records from Carberry, Shoal Lake, Norway House, etc.

50. Hoy Shrew, Mír,rosorex hoyi (Baird). All of Manitoba falls within the known range of this species. Yet there is but one actual record, that from Red River Scttlement.

j1. Marsh-shrew, Neosorex palustris (Richardson). All Manitoba falls within its krown range. but there are only two or three records. It is an inhabitant of marshes and river banks, nowhere common.

5.). Mole-shrew, Blarina brevicauda (Say). Found only in the woods east of Winnipeg; common there.

i.). Star-nosed Mole, Condylura cristata (Iinnaeus). Recorded once from Winnipeg, but rare, and near the west end of its range at this point.

i). Little Brown-bat, Myotis lucifugus (Le Conte). All Manitoba falls within its known range. But I know of but one specimen taken within our limits; that I got from Poplar Point.

5.). Say Bat, Myotis subulatus (Say). The accredited range of this Bat includes Manitoba, and the re- 
cords nearly surround the Pro: : ce, but it has not yet been taken in our limits.

i). Silver-haired Bat, Jasionyctcris noctivagans (I,e Conte). This species is commonly and generally distributed in Manitoba. It comes from the south about the vernal, and retires about the autumnal equinox.

57. Big Brown-bat, Eptesicus fusu us (Beauvois). There is a single Lake Winnipeg record for this species. Its proper range is to the southward, and Manitoisa is its northmost limit so far as known.

is. Red-bat, Lasiurus borealis (Nuller). The reco is show that this handsome bat is found in all the south-western part of the Province as a summer visitant.

5) Hoary-kat, Lasiurus cinereus (Beauvois). This rine specie 3 is found in all parts of Manitoba. It is somewhat common, and, like the rest of our Bats. is a migrant, never, so far as known, hibernating vithin our limits.

\section{THE BIRDS OF MAIJTOBA}

(The nomenclature used is that of the A.O.U. 'atest check list )

1. Swan-grebe, Western Grebe. Aeclmophon ocit dentalis. Common summer resident in parts oi th Alleghanian region, chicfly towards the north. Quive common at Shoal Lake, near Lake Manitolad, breeding in colonies in the marshes about Lake Winnepegosis. Very local in distribution.

2. Silver-cheelred Grebe, "olbœll Grebe. Colymbus holboclli. Summer resident in Red River Valley. 
Breeding in most of the large marshes of the Alleghanian portion of Manitoba.

3. Horned Grebe. Criymbus auritus. Abundant sinmer resident throughout the Province, April io October.

4. American Eared-grebe. Colymbus nigricollis californicus. A common summer resident in all the prairie region, but rot yet found in the Canadian or north-eastern hali of the Province.

5. Pied-billed Grebe, Dabchick. Podilymbus podiceps. Common summer resident in all parts of the Province where there are small ponds, from mid-April to October.

(i. Loon. Gavia immer. Common summer resident on all the large lakes and rivers that are well supplied with fish.

7. Red-throated Loon. Gavia stellata. Rare; known only as a migrant.

S. Long-tailed Skua. Stercorarius longicaudus. In September, 1896, Samuel Slater brought to Alexander Calder of Winnipeg, in whose collection it now is, an immature Long-tailed Skua, shot on Lake Winnipeg. Its dimensions are: Length, 161/2 inches; wing 12 inches; tail $61 / 2$ inches; taisus, $13 / 4$ inches; middle toe and claw, $13 / 4$ inches. All above sooty, exc.pt the neck, which is cream color, and crown, which is sharply blackish.

9. American Herring-gull. Larus argentatus. Abuncunt; of general distribution. Breeding in all the large lakes and prairie ponds. Arrives April 20.

10. Ring-billed Gull. Larus delawarensis. Common summer resident. Breeding in all the lakes and iarge prairie ponds.

11. Franklin Gull, Rosy Gull. Larns franklini. Abun- 
dant; common summer resident, breeding in most of the large marshes of the Alleghanian region.

12. Bonaparte Gull. Larus philadelphia. Regular summer visitant. A few oreed on the large lakes of the Province region.

13. Forster Tern. Sterna forsteri. Common summer resident, breeding about the larger lakes.

14. Common Tern. Stern. hirundo. Common sumnıer resident on the large lakes, breeding with the i receding.

ii). Black Tern. Hydrocheliton nigra surinamensis. Abundant summer recident everywhere, breeding in colonies on the prairie ponds. Arrives May 20; departs August :30.

16. Double-crested Cormorant, Crow-duck. Phalacrocorax auritus. Generally distributed, and breeding in colonies about the large lakes of the Alleghanian part of the country.

17. American waite Pelican. Pelecanus erythrorhynrhos. Apparently of general distribution, breeding about most of the lakes, chiefly west of Lake IVinnipeg: less numerous than formerly.

18. American Merganser, Sheldrake. Mergus americanus. Common summer resident, breeding commonly in the rive!s of the Lake Winnipegosis basin.

19. Red-breasted Merganser, Fish-duck. Mergus serrator. Common summer resident. Generally distributed, but breeding only in the northernly parts of the Province.

20. Hooded Merganser. L.ophodytes cucullatus. Common slimmer resident of general distribution, 
breeding wherever it finds hollow trees near the water.

21. Mallard. Anus platyrhycuhos. Very abundant summer rosident everywhere, breeding in all marshes. Arrives April 15; departs late in October.

2.2. Black Mallard or Dusky Duck. Anas rubripes. Very rare. Three or four specimens taken at Long Lake in four years. In my collection is a specimen fron Shoal Lake, taken by Geo. H. Measham in 1901, and another taken near Winnipeg, by II. R. Hine. According to Measham, two more were shot at Shoal Lake in 1899 . C. C. 11 liwell reports one taken on Lake Manitoba in the fall of 189S.

2:3. Gadwall. Chaulelusmus streperus. Common, breeding about all the large lakes and the ponds of the prairie region.

24. Baldpate or Widgeon. Mareca americana. Summer resident. Not common, but generally distributed and breeding.

2:). Green-winged Teal. Nettion carolinense. Abundant summer resident everywhere; breeding. Arrives April 20; departs in October.

26. Blue-winged Teal. Querquedula discors. Very abundant summer resident. Arrives late in $\Lambda$ pril; departs early in October.

2-. Shoveller. Spatula clypeata. Common summer resident everywhere. Departs late in October. like the other Ducks, when the frost seals the ponds.

29. Pintail. Dafila acuta. Common summer resident, breeding. Arrives late in mid-April; departs in October. 
29). Wood-duck. Aix sponsa. A rire but regular summer visitant as far north as Lakes Winnipeg and Hinnipegosis. I saw a pair taken at Carberry in 1883, and in 1891 got a male at Kenora. It is reported from Cook's Creek. Westbourne, Portage la Prairic, Lake Winnipegosis. Over at dozen were taken on the Souris River, about "i) miles southwest of Brandon, between $18 \$^{\circ} \mathrm{E}$ and $1899, \mathrm{by} \mathrm{H}$. $\mathrm{W}$. O. Boger. Three were killed at Brandon be C. C. Helliwell, who saw also two on the roof of the town station, one day about $1, \$ 9()$. G. H. Measham reports it rare at Shoal Lake, but one or two are secn there each year.

These, with previous records, completely spot the map of south-western Manitoba. The species is doubtless found throughout the Alleghanian region of the Province, as it has been recorded from Qu'Appelle and Cumberland House.

i). Redhead. Marila anericana Abundant summer resident of the Alleghanian region. Arrive:; in April: departs in October.

:3) Canvas-back. Marilı z'allisneria. Cienerally distributed in the Alleghanian region and brecoling, but nowhere comnion.

32. American Scaup-duck, Big Blue-bill. Marilı marila. Common in spring an'l fall in all parts of Manitoba: a few may breed in the northern district. Arriva late in April; departs in October.

:3.). Lesser Scaup-duck, Little Blue-bill. Marilı affinis. Very abundant summer resident in all parts of the Province. Breeds.

34. Ring-necked Duck, Marsh Rlue-bill. Marila coilaris. I rare summer resident. Reported from Winnipeg. P'ortage la Prairic, Waterhen River. 
35. American Golden-eye, Whistler. Clangula americand. A common summer resident in all parts of Manitoba where there are large trees near water.

36. Barrow Golden-eye. Clangula islindica. "I shot a brace at Lake Manitoba in 1879, and a drake at Shoal Lake in the spring of the following year. And I saw a drake which was killed at the mouth of the Red River." (R.H. Hunter.)

37. Bufflehead. Charitonetta albeolu. Common summer resident wherein there is timber and water. Arrives April 15; departs in October.

3s. White-winged Scoter. Oidemia deglandi. Sum.mer resident, breeding in marshy ponds. Found it quite common at Shoal Lake.

39. Surf Scoter. Oidemia perspicillata. Rare migrant: reported from Lake l'innipeg (Hine), Red River (Hunter), Nelson River (Blakiston).

40. Ruddy Duck. Erismatura Jamaicensis. A summer visitant; not common, erratic in distribution. Breeds in most of the large marshes.

41. Blue Goose, Silver Brant. Chen cacrulescens. Noted as a rare migrant. Specimens taken at Winnipeg, Portage la Prairie and Brandon. At Fort Chipewyan, Lake Athabaska, where 10,000 or more geese were killed each autumn, only one of this species was taken in several years. This is now in my. collection.

42. Snow-goose, Wavey. Chen hyperborea. Abundant spring migrant; less common in the fall. Arrives May 15, and again in October.

43. Ross Goose. Chen rossi. A specimen was taken on Red River near Winnipeg by Frank Marwood of that city, Sept. 20, 1902. It is now in the collection of Alexander Calder at Winnipeg. 
44. White-fronted Goose. Anser albifrons gambeli. Rare, but regular migrant.

45. Canada Goose, Wild Goose. Branta canadensis. Abundant in the migrations. Arrives in April; departs late in October.

45. Hutchins Goose. Branta canadensis hutchinsi. A rare migrant or straggler. Taken on Red River by Kennicott, observed at Portage la Prairie by C. W. Nash, and noted at Brandon by: C. C. Helliwell.

46. Brant. Branta bernicla glaucogastra. A rare migrant.

47. Whistling Swan. Olor columbianus. A rare migrant of general distribution.

48. Trumpeter Swan. O!or buccinator. A very rare migrant. George H. Measham secu:ed three on Roseau River. A single specimen is in Manitoba Museum.

49. American Bittern. Botaurus lentiginosus. Common summer resident; of general distribution, especially about the extensive marshes of the Alleghanian region. Arrives the middle of $A$ pril: departs in October.

50. Least Bittern. Ixobrychus exilis. Very rare summer visitant. On Nov. 9, 1907, E. W. Darbey showed me a Least Bittern, a young male, that was taken about Oct. 20 at Oak Point, Lake Manitoba, by J. C. McNab.

According to $W$. R. Hine, a specimen was shot in the Bishop's Marsh near St. Boniface in 1885 by Wn. Gordon (of Winnipeg). C. C. Helliwell has seen one or two about Oak Lake, Manitoba. Frank M. Chapman saw one at Shoal L,ake, June, 1901.

51. Great Blue Heron. Ardea herodias. Generally distributed as a summer rerisont; nowhere common. 
52. American Egrot. Herodias egretta. In the summer of 1883, David Armit, an officer of the Hudson's Bay Company stationed at Manitoba House, while out shooting at Duck Buy, Lake Winnipegosis, came across and collected a fine adult specimen of this bird in breeding plumage. He has most generously sent the prize to me; it is now No. 1,776 of $\mathrm{my}$ collection. This is, I believe, the northernmost frecord for the species.

j.). Black-crowned Night-heron. Nycticorax nycticorax naeivs. Summer resident of general distribution in the Alleghanian region. I found it quite numerous and breeding in colonies at Shoal Lake. In other parts of the region it is somewhat rare.

54. Whooping Crane. Grus americana. Former!v coinmon and breeding; now nearly extinct.

5.). Little Brown Crane. Grus canadensis. Summer resident of general distribution; much less common than formerly. Arrives in mid-April; departs in September.

56. Virginia Rail. Rallus virginianus. Rare, but regular, summer resident of the Alleghanian region. The specimen in my collection was taken near Morden by D. Nicholson. I saw another in the collection of Geo. F. Atkinson of Portage la Prairie, and heard of another at Brandon. I have seen several taken near Winnipeg.

57. Sora, Common Rail. Porzana carolina. Abundant summer resident throughout Manitoba. Arrives May 1; departs in October.

58. Yellow Rail, Water Sparrow. Coturnicops novebo. racensis. On the 13 th of July, 1883, a specimen of this Rail was brought to me alive, by a farmer who caught it in a slough where he was cutting wild hay. 
Being just then called away, I placed the bird in a coop, and on my return it was gone. But the record is, I believe, safe, as Preble found the species numerous at York factory, and there are other records to completely surround the Province.

59. American Coot. Fulica americana. Abundant summer resident. Arrives in mid-April; departs late in October.

(0). Northeru Phalarope. Lobipes lobatus. Rare straggler in migration; noted about Winnipeg only.

61. Wilson Phalarope. Steganopus tricolor. Common summer resident, breeding on most of the large ponds and marshes in the Alleghanian region.

(i2. American Avocet. Recurvirostra americana. While abundant in the adjoining Province of Saskatchewan, the species is a rare stı aggler in Manitoba.

R. H. Hunter writes: "I have killed the bird along the Souris, south-west of Plum Creek." In the Museum of the Geological Survey at Ottawa is a specimen of the Avocet, marl": d "from Manitoba." Shaw Cottingham killed neariy a dozen at a place 9 miles south of Brandon in 1899 , and $\mathrm{C}$. C. Helliwell got three or four out of a flock at Oak Lake, ten years before.

6.3. American Woodccik. Plulohela minor. Very rare summer resillent. At Winnipeg $W$. R. line reports that he got four during four years. At Portage la Prairie, one or two pairs seen each year by C. W. Nash. At Stuartburn, on Roseau River, George H. Measham shot one in 1891.

64. Wilson Snipe. Gallinago delitcata. Abundant $\lrcorner \mathrm{m}$ mer resident on all extensive bogs. Arrives April 20: departs September 30.

65. Dowitcher. Macrorhamphus scolopaceus. Abundant migrant in the western part of Manitoba. 
66. Stilt Sandpiper. Micropalama himantopus. On August 29, at Carberry, I made the first positive capture of this species in the Province. It was in a mixed flock of Sandpipers of several species.

67. Knot, Robin Snipe Tringa canutus. Occasional migrant; noter along Red River and west of Brandon.

68. Pectoral Sandpiper. Pisobia maculata. A common migrant; noted along Red River.

69. White-rumped Sandpiper." Pisohia fuscicollis. Migrant; sometimes common, chiefly in western Manitoba.

70. Baird Sandpiper. Pisobia bairdi. Common migrant, chiefly in Angust.

71. Least Sandpiper. Pisobia minutilla. A common migrant in all the western part of the Province, especially during August.

72. Red-backed Sandpiper, Blackheart. Pelidna alpina sakhalina. Reported a common migrant along Red River (Hine) and at Portage la Prairie in fall (Nash). I have not seen a Manitoba specimen.

73. Semipalmated Sandpiper. Ereunctes pusillus. Generally distributed as a migrant; especially abundant in the country west of Red River.

74. Sanderling. Calidris lucophaea. Common migrant; recorded from Lake Winnipeg, Lake Manitoba, Portage la Prairie and Oak Lake.

75. Marbled Godwit. Limosa fedoa. Summer resident, frequenting the wet prairies near Winnipeg and on the plains of the Souris, etc. Formerly common, now becoming rare.

76. Hudsonian Godwit. Limosa haemastica. A rare migrant, chiefly along Red River and westward.

77. Greater Yellow-legs. Totanus melanoleucus. Abun- 
dant migrant. Spring migration, late in April; fall, early in August.

78. Yellow-legs. Totanus flavipes. Abundant migrant in mid-May and in August.

79. Solitary Sandpiper. Helodromas solitarius. Common migrant, especially in fall; probably also it breeds.

80. Western Willet. Catoptrophorus semipaimatus inornatus. Common summer resident on all the wet prairies of south-western Manitoba.

\$1. Bartramian Sandpiper, Prairie Plover. Bartramia longicauda. In early days this was an extremely abundant summer resident on all the prairies of the Province. It has now become very scarce. Arrives May 7; departs August 30.

S2. Spotted Sandpiper. Actitis macularia. Common summer resident. Arrives May 1, departing late in September.

\$3. Long-billed Curlew. Numenius americanus. Summer resident on the wet prairies of the Red River and on the Souris. Formerly common about Lake Manitoba, now rare.

81. Black-bellied Plover. Squatarola squatarola. Rare spring migrant; no autumn records.

Si). American Golden Plover. Charadrius dominicus. Common spring and fall migrant. Affects burnt prairies and ploughed land. Spring migration, midile of May; fall, in August and September.

s6. Killdeer. Oxyechus vociferus. Common summer resident throughout the Province. Arrives late in April; departs last of August.

87. Semipalmated Plover, Ring-plover. Aegialitis semipalmata. Rare nigrant.

ss. Belted Piping Plover. Aegialitis meloda. Some- 
what common, migrant throughout the Province, and, according to Macoun, found actually breeding on Lakes Manitoba and Winnipeg.

89. Turnstone. Arenaria interpres morinella. A rare migrant. Goes north about May 15; returns about August 15.

90. Spruce Grouse. Canachites canadensis. Common permanent resident of all the Canadian or northeastern half of the Province.

91. Canadian Ruffed Gro'se. Bonasa umbellus togata. Common permanent resident of the Canadian portion of Manitoba.

91a. Gray Ruffed Grouse. Bonasa umbellus umbelloides. Abundant resident of the Alleghanian or south-western half of the country whereon there is woods.

92. Willow Ptarmigan. Lagopus lagopus. A common resident of the extreme northern parts of Nanitoba, moving southward in winter as far as Shell River, Lake Manitoba and Shoal Lake.

93. Prairie-hen. Tympaunchns americauns. In 1871 Dr. Coues wrote: "I have no reason to believe that it occurs at all in North-western Minnesota or Northern Dakota." In 1882, when first I visited Manitoba, the species was nearly unknown in the country, the only known specimen having been taken near Winnipeg in 1881 . In 1883 W. R. Hine, infurms me, it began to be common at Pembina. In $188+$ it was not only common at Winnipeg, but had also for the first time made its appearance at Portage la Prairie, on the Assiniboine. In 1886 I first saw it at Carberry. Since then it has spread with cultivation, and is now abundant in all the settled parts. 


\section{Columbian Sharp-tailled Grouse, Prairie Chicken.} Pediocaetes phasianellus columbianus. Abundant resident everywhere, especially in the country west of Lake Winnipeg. north to the narrows of Lake Winnipeg, and thence eastward as far as Long Lake and Pic River, on Lake Winnipeg (Bell). This species lives by preference on the prairies in summer and in the wooded districts during winter, so that it is in a sense 1nigratory.

95. Passenger Pigeon. Ectopistes migratorius. In 188:) I wrote as follows: "Common summer resident, - probably everywh're, as it was noted on Riding Mountain, along the Assiniboine, on Big Plain, on Turtle Mountain (Coues) and nurthward, as well as al! over the Red River Valley. throughout the Winnipegosis region. Often abundant during the migrations. I an not aware of the existence of any extensive 'rookeries.' Arrives early in May; departs in October."

In 1908 my notes on the species are: "The following are all the specimens I know of in Manitoba:Adult male taken at Winnipes' ${ }^{\prime}$ 1592, now in collection of Father Blain, St. Boniface College; adult male taken at Winniper in 1894 by E. Wilson, now in possession of J. K. Hardy of St. Boniface; adult male taken at "innipegosis on $13 A_{p}$ ril, 1898, by J. J. G. Rosser."

The last year in which the Pigeons came to Manitoba in force was 1878. Next year they were comparatively scarce, and each year they have becoms more so. In the eurly eighties a few were seen each season. The above three specimens were the late reliable recorded. None lave been seen since. It is interesting to note that 1878 was also the last year of the vast Buffalo herds on the Saskatchewan. In my collection are three specimens of Passenger 
Pigeon: young male taken at Carberry, Man., by Miller Christy, 30 Aug.,1883; adult male and female taken at Fort Hulnies, Ind. T., U.S., by C. Dewar, Jan. 1889.

96. Mourning Dove. Zenaidura macroura carolinensis. Formerly far from common, now abundant in all parts of the Alleghanian region where there is timber, frequenting barnyards that are near the wouds.

97. Turkey Vulture. Cithartes aura septentrionalis. Common summer resident of the piairie region, probably breeding here.

98. Swallow-tailed Kite. Elancides forficatus. Geo. Grieve tells me that two have been taken at Winnipeg, one in 1889 and one in 189.2 , neither seen by me. I observed one in Minnesota, near Pembina, in 1883. Coues re orts it as occasional at Pembina, and R. H. Hunter writes me that he has seer. it at Selkirk, Pembina Mountain, and Fort Qu'Appelle.

99. Harrier. Circus hudsonius. Abundant summer resident. The adults, in blue plumage, are common in spring and fall. Arrives April 15; departs October 15.

100. Sharp-shinned Hawk. Accipiter velox. Cunımon summer resident in all wooded regions. Arrives April 15; departs October 15.

101. Cooper Hawk or Chicken Hawk. Accipiter couperi. May be entered as a rare summer resident. Reported by Hine and Hunter. I saw one at Edmonton, but lo not know of a specimen taken in the Province.

102. American Goshawk. Astur atricapillus. Conmon fall and winter visitat, usually appearing in August. Not noted during the breeding season. 
10:3. Red-tailed Hawk. Buteo borealis. Common summer resident of the wooded regions. Apparently complementary of the Swainson Hawk, which is found in more open country and on the prairie. Arrives April 15; departs October 15.

103a. Krider Hawk. Buteo borealio krideri. Three specimens of this beautiful Hawk have been taken at Winnipeg--one shot at Rosenfeld by Charles Stewart, Sept. 20, 1905; two now in the collection of A. Calder.

101. Red-shouldered Hawk. Buteo lineatus. R. H. Hunter writes me that he found this species in Eastern Manitoba.

105. Swainson Herk. Common Henhawk Buteo sie'rinsoni. Very abundant summer resirlent of the prairie region; breeds perhaps iwice each season. Have seen several black specimens. Arrives April 15; departs October 15.

10(i. Broad-winged Hawk. Buteo platypterus. Regular summer visitant wherever there is woods. In my collection are two specimens, one collected near Winnipeg May $3,19 \%$, by Ashley Hine. It is reported from vario" arts of the Province where well timbered, and enerally distributed, though not abundant. A. Caider has a beautiful n latnistic specimen, killei at Wimnipeg, April, 1907.

107. American Rough-legged Hawk. Archibuteo lugopus sancti-johannis. Nigrant; only scen in spring and fall, but not numerous.

109. Red Roughleg, Gopher-hawk. Archibuteo ferrugineus. One in the collection of E. W. Darbey was shot, in 1895, at Nivarville, fifteen miles south-west of Ilinniper, by cico. Grieve. There is another speciniter in thr Manitoba Museum. 
109. Golden Eagle. Aquila chrysuetos. Rare, but apparently resident.

110. Bald Eagle. Haliaetus leucocephalus. Summer visitant, of general distribution wherever there are fish.

111. Cay Grrfalcon. Falco rusticolus. A rare winter v.sita:lt. A specimen was killed near Winnipeg in the fall of 1904 , and mounted by E. W. Darbey for the Manitoba Museum. Two fine specimens taken by $W$. R. Hine were at one time in the same collection.

112. Duck Hawk. Falco peregrinus anaturi. Much like the Goshawk in movements and distribution. Probably fireeds in the neighborhood of the large lakes. Quite conımon on the Big Plain ahrut August.

113. Pigeon Hawi. Filco columbarius. Commori spring and fall inigrant, breeding in the woods of northern Manitoba.

113a. Richardson Merlin. Falco columbarius richardsoni. A Plains race, said to be a regular summer resident along Souris River. A fine specimen was killed in Winnipeg during the summer of 1900 and brought in the flesh to $\mathrm{A}$ Calder, in whose collection it may now be seen.

114. American Sparrow-hawk. Falcospurcerius. Abundant summer resident: of general distribution wherever there is woods.

115. American Osprey. Pandion haliaetus carolinensis. A summer resident about all the fish-stocked rivers and lakes. Reported from all parts of the Province, but rare.

116. American Long-eared Owl. Asio uilsoniants. Sum- 
ner resident in ali wooded sections. Arrives April 15; departs October 20.

117. Short-eared Owl, Marsh-owl. Asio flanmeus. Common summer resident in all marshy and prairie sections. Arrives April 1; departs October 30.

118. Barred Owl. Strix varia. Summer resident of the wooded sections. The records show it to be more widely differed than was once believed. In 1886 I saw a specimen taken at Kenura. In my collection is one taken at Winnipeg, March 30, 1906, by Harry Jones. E. W. Darbey writes me that he had four, taken at Winnipeg in 1906). and one early in April, 1908. At Portage la Prairie I was shown a female taken by G. E. Atkinson, May 19, 1899. J. S. Charleson writes me that on May 9,1901 , while canoeing up the Assiniboine near $W$ innipeg, he saw a Barred Owl in a tree. Also he secured a specimen from Rirling Mountain in January, 1905; it was killed by T. S. Kittson, and had in its stomach a flying squirrel. Arrives about April 1; departs about November 1.

119. Great Gray Owl. Siotiaptex nebulosa. One specimer, taken on the Big Plain, September 29, 1884. Rather common along the Red River, and resident in the woods about Lake Winnipeg.

120. Richardson Owl. Gluux funerea richardsoni. A cornmon winter visitant in the Alleghanian region, but probably resident and breeding in the Canadian part of the Province.

121. Saw-whet Owl. Glaux acadica. Rare, but apparently a permanent resident.

122. Western Horned Owl. Bubo virginianus pallescens. Common resident wherever there is woods.

122a. White Horned Owl. Bubo virginianus subarcticus. 
Rare in Manitoba; in A. Calder's collection are two superb specimens of this northern form. They were taken recently at Winnipeg. It is recorded also from MacDonald, Duck Mountain, anrl Tuuchwood Hills.

123. Snowy Ow!, White Owl. Nyitea ny'tea. Common winter visitant, sometimes appearing in large numbers. Arrives October 1; departs April 15.

124. American Hawk-owl. Surnia ulula caparoch. Very abundant some years. Arrives late ii September, and remains until April. May yet be found breeding in the extreme north of the Province.

125). Burrowing Owl. Speotyto innicularia hypogaea. There is one of the species that have appeared in Manitoba recently. In the early eighties it was quite unknown.

In August, 1899, at the taxidermist shop of G. E. Atkinson, Portage la Prairie, I saw two Burrowing Owls that were taken by a farmer about four miles north-west of the town, on June 2, 1897. Two others were brought to the shop in May, 1899. The specimen in my collection (No. 2,5)(9t) is one of two taken at Morden by D. Nicholson, the taxidermist. He reports it rare, but regular and increasing. Two others were taken in 1902. E. W. Darbey tells me that it is becoming quite common along the Pipe. stone and on the slope of Riding Mountain.

In $1904 \mathrm{~J}$. P. 'Turner found a nest eight miles north-west of Winnipeg. The species utilizes the burrows of the Richardson ground-squirrel for a nesting place.

126. Black-billed Cuckoo. Coccyzus erythrophthalmus. A comnion summer resident in all the Alleghanian region, not yet recorded beyond that limit. Arrives late in May, departing at the end of August. 
127. Belted Kingfisher. Ceryle alcyon. Common summer resident everywhere along streams and fish frequented lakes. Arrives April 20; departs in October.

128. Northern Hairy Woodpecker. Dryobates villosus leucomelas. Common resident of woods everywhere.

129. Downy Woodpecker. Dryobutes pulescens medianus. Common resident throughout the Province, excepting possibly the north-eastern corner.

130. Arctic Three-toed Woodpecker. Picoides arcticus. Common resident in the forested region. Most plentiful in winter, therefure probably in some degree migratory.

131. American Three-toed Woodpecker. Picoides amcricalnus. Rare permanent resident of the Canadian region. Unfortunately no specimens are available. Both W. R. Hine and R. H. Hunter claim to have seen it in the woods east of Winnipeg, and at Kenora, in 1886, I saw a supposed specimen, beside which its known range includes the forested portion of the Province.

132. Yellow-bellied Sapsucker. Sphyrupicus varius. Common summer resident of all the Alleghanian region; not yet recorded from the Canadian. Ar. rives about May 1.

133. Pileated Woodpecker, Cock-of-the-Woods. Phloeotomus pileatus abieticola. Rare resident in heavy

134. Red-headed Woodpecker. Melanerpes erythrocephalus. A rare summer resident of south-western Manitohi, apparently confinerl to regions where oaks are found.

135. Flicker, Highholder. Colaptes aunrats luteus. Very 
abundant summer resident throughout the Province wherever there are trees. Arrives April 15; departs September 30.

136. Red-shafted Flicker. Colaptes cafer collaris. A full plumaged female in my collection (No. 2,5t(i) was shot near Winnipeg, Sept. 30, 1904, by T. Dolphin. At Portage la Prairie, in Auglist, 1899, I saw in G. E. Atkinson's taxidermist shop a fine adult hybrid Flicker, shot in the vicinity, April 16, $189 \%$.

137. Whip-poor-will. Antrostomus vociferus. Abundunt summer resident in woods and partly wooded regions throughout the Province.

138. Night-hawk. Chordeiles virginiauns. The Nighthawk is common throughout Manitoba, and thus the typical form seems to be the one in all but the true prairie region.

138a. Western Night-hawk. Chordeiles virginiunus henryi. Very abundant summer resident of the prairies in south-western Manitoba. Arrives May 24; departs August 30.

139. Chimney Swift. Chaetura pelagica. Summer resident of the Alleghanian region, nowhere very common, and most numerous about the towns. Arrives about May 15; departs early in September.

140. Ruby-throated Hummingbird. Trochilus colulris. This is a summer resident in the Alleghanian region, wherever it finds suitable surroundings-that is, a warm sheltered garden with red flowers. Arriving about May 23.

141. Scissor-tailed Flycatcher. Muscivoru forficatu. Accidental straggler. One found by C. W. Nash, at Portage la Prairie, October 31, 1884. (Scee Auk, April, 1885, p. 218.)

142. Kingbird. Tyrannus tyrannus. Very abundant 
summer resident throughout the Province wherever there are trees or even small bushes. Arrives May

143. Arkansas Kingbird. Tyrannus verticialis. Two specimens of this, an adult and one in first plumage, were taken by D. Lush Thorpe at the Souris coal $f$ 's, August 20, 1891. This is not many miles to the rest of the Province, and justifies the insertion of the specics as probably Manitoban.

144. Crested Flycatcher. Myiurchus crinitus. Suminer rtsident about Winnipeg; noted severa! times at Carberry. Taken by Professor Macoun at Lake Manitoba, June 17, 1S81. Quite common along the Assiniboine. On Aug. 20, 1904, I got one at I,ake IVinnipegosis. This is the northernmost that I know of.

14.. Fhoebe. Sayornis phoelve. Rare summer resident, but apparently found in all parts of the Province; recorded even from Norway House.

146. Olive-sided Flycatcher. Nuttallornis horealis. A common summer resident in al! the wooded parts of the Province.

147. Wood Pewee. Myiuchanes virens. Summer resident of the heavy woods in the Alleghanian region.

14S. Western Wood Pewee. Myicchancs richardsoni. Common summer resident of the willow thicket and open groves throughout the Alleghanian region.

14!). Yellow-bellied Flycatcher. Empidonax flaviventris. Summer resident, frequenting woodlands. Noted at IVinnipeg, Portage la Prairic, Duck Mountain, and Oak Lake. Probably throughout the Alleghanian region.

150. Alder Flycatcher. Empidonax trailli alinorum. Recorded from Pembina, Carberry, Lake Manitoba, 
Duck Mountain, Riding Mountain, and Norway House, so doubtless it is generally distributed throughout the Province wherever there is cover. An abundant summer resident.

151. Loast Flycatcher. Empidonax minimus. Very abundant summer in all wooded localities. Arrives May 20; departs late in September.

152. Prairie Horned Lark. Otvcoris alpestris praticola. Abundant, breeding in all the prairic regions. Resident, excepting during December, January, and February. Breeds twice each season.

152a. Shore Lark. Otocoris alpestris. Fall migrant. Taken at Carberry and Kenora.

153. Americar Magpie. Pica hudsoniu. Irregular, rare resicinı. Found west of Fort Ellice, and occasionally along the Upper Assiniboine. A single specimen reported from Brandon.

154. Blue Jay. Cyanocitta cristata. Common summer resident of woodlands throughout the Province. Arrives early in April; departs late in November. May be resident in southern localities.

155. Canada Jay, Whiskey-jack. Wis-ka-tjan, Perisoreus canadensis. Abundant resident throughou. the wooded region. The common name of this bird is a corruption of the Indian Wis-ka-tjan. This last name should not be lost sight of.

156. American Raven. Corvus corax principalis. Winter visitant in all the Alleghanian region. Said to be resident, and of course breeding, in the Canadian regions to the north; not common anywhere.

157. American Crow. Corvus brachyrhynchos. Summer resident throughout the Province. Abundant in the Alleghanian region: scarce in the Canadian. 
1is. Bobolink. Dolichonyx oryzizortes. Abundant sum. ner resident in all the prairie region. Arrives May
20 , departs September 7 .

159. Cowbird. Molothrus ater. Very ibundant summer resident throughout the prairie region. Arrives May 1.); departs 'te in the fall, but disappears for a time during 1 : moult at the end of August. They are then to be found, I believe, in the sloughs and marshes with the Cirackles.

Iril). Yellow-headed Blackbird. Xunthocephalus xanthocephalus. A summer resident of the marshes throughout the Alleghanian region; found also, but much less numerously, in the Canadian region: wherever there are extensive marshes. Arrives May 1, departs late in October.

161. Northern Redwing. Agelaius phoeniceus critolegus. Abundant summer resident of the whole Province. Arrives April 20; reparts late in October.

l(i:. Western Meadow Iar!s. Sturne!la neglectu. Abundant sumrer resident of all the prairie regions. Arrives April 1.5; departs October 15.

16i3. Orchard Oriole. Iiterus spurius. One specimen, taken at Pembina, June 6, 1873, by Dr. Coues.

164. Baltimore Oriole. Icterus gaioula. Abundant summer resident of the Alleghanian region. Arrives May 30; departs August 30.

16i5. Rusty Blackbird. Euphagus carolinus. Extremely abundant migrant during April and late September. Not found in the Alleghanian region during summer, but probably breeding in the north-west parts of the Province within the Canadian.

166. Brewer Blackbird, Satin Bird. Euphagus cyanocephalus. Abundant summer resident, apparently 
confined to the Alleguanian region. Arrives April 1); departs November 1.

16iT. Bronzed Grackle. Quisculus quiscula aeneus. Aburdant summer resident wherever there is woodland. Arrives April 2(1, departs October 1:).

16.. Evening Grosbeak. Hesperiphonu vespertina. Common winter visitant in the vicinities of Winnipes. l'ortage la Prairie, and Qu'Appelle, Big Island in lake Winnipeg, and Selkirk. (K. H. Hunter.)

169. Pine Grosbeak. Pinicolı enucleator leucura. Common winter visitant in all the wooded sections, probably breeding in the northmost parts of the Province.

Purple Finch. Corpodacus purpureus. Common summer resident of all wooded regions. Arrives carly in May; departs middle of September.

171. English Sparrow. Passer domesticus. This species is now found in all the settled portions of Manitoba, and at every farmhouse and in all the towns of the North-west as far as Athabaski: Landingr, Alberta, about N. Latitude 5i). W. Longitude 11:3. It first appeared at Carberry iii $189^{\circ}$, but was not found in numbers until 1894. According to Criddle, it is developing a habit of migration.

17.2. American Crossbill. Loxia curvirostr! minor. Common as a winter visitant at Winnipeg, Purtage la Prairie and Big Plain, possibly breeding, ats it is known to do so in Minnesota (Trippe).

173. White-winged Crossbill. Loxia leucoptera. Conmon winter visitant about Winnipeg and Big Plain; may breed in the Canadian region.

174. Gray-crowned Finch, Pink Snowbird. Leucosticte tephrocotis. I have in my collection an adult of species taken near Birtle. Manitoba, in January. 
1891, by Grofye iopeland. Also in the Manitoba Muse nare two specimens taken in the Province by $W$ ?. Hine These give a considerable eastwarl extension to the range of the species.

17.). Hoary Redpoll. Acunthis hornemanni exilipes. Noted only as a rare nigrant; in fall and winter accompanies A. linaria.

17i. Redpoll. Aidnthis !inaria. Abundant fall and winter visitant, arriving from the north about October 삐, and departing about May 1.

177. American Goldfinch. Astrugalinus tristis. Common summer resident of the Alleglianian region. Arrives last week of May; departs middle of September.

17s. Pine Siskin. Spinus pin!s. In irregular and abundant spring and fall visitint; may breed in the Canalian region.

179. Snowflake, Snow-bunting. Plectrophenax inivalis. Very abundint spring, fall, and winter resident, arriving about the midelle of October and staying until the end of Aprii.

IS(). Lapland Longspur. Culcurius lapponicus. Very abundant spring and fall migrant. Arrives May. $1 ;$, and again September 20 .

1S1. Painted Longspur. Calcarius pictus. Abundant spring, and much les; plentiful fall migrant. Arrives on May 10 , stays two weeks, and again on September 1.5 for a few days.

13.). Black-breasted Longspur. Corlcaritis ornatils. Common summer resident of the dry prairies. Local in distribution, man! pairs sometimes affecting a limited area of dry prairie, while again for miles no more of the species are to be seen. Arrives May li;
departs August 30 .

15:3. McCown Longspur. Rhynchophanes mecinini. 
specimen of this bird. taken by D. Losh Thorps near Dalesbro, just west of our borders, justifies its inclusion as a probable straggler.

1S4. Western Vesper-sparrow. Pooecetes gramineus confinis. Very abundant summer resident of the prairie region. Arrives May 1; departs September 30.

155. Savanna Sparrow. Passerculus sundicichensis savanna. Doubtless found as a summer resident in open places throughout our Canadian area, as Preble found it general in Keewatin and at Norway House.

1S5̄a. Western Savanna-sparrow. Passerculus sandwichensis alaudinus. Abundant summer resident of the prairie region. Arrives May 1; departs September 30 .

186. Baird Sparrow. Coturniculus bairdi. Abundant summer resident throughout the prairie region wherever there are alkaline flats. Taken at Grand Rapids (Nutting).

1S7. Leconte Sparrow. Ammodramus lecontei. Abundant summer resident of willow bottom-lands throughout the prairie region. Arrives May 1; departs September 30.

189. Nelson Sparrow. Ammodramus ne?soni. In 1892 I found this sparrow abuildant at Carberry and secured specimens, both breeding and migrant. In 1901 I found it common at Shoal Lake. In my collection are three specimens taken at Winnipeg. There can be little doubt that it is found throughout south-western Manitoba, and breeds wherever found.

189. Lark Sparrow. Chondestes grammacus. Rare summer resident. Noted only in the vicinity of Winnipeg and at Portage la Prairie. 
190. Black-faced or Harris Sparrow. Zonotrichia querula. Abundant spring and fall migrant. Arrives May 15 and again September $: 0$, remaining a week or ten days each time. Breeds in Hudsonian fauna. Nest found in far north. See Auk, Jan. 1998, p. 7:2.

191. White-crowned Sparrow. Zonotrichia leucophrys. Migrant, not common. Passes through in early May and late September. Probably breeds in the extreme north-eastern part of the Province.

191a. Gambel Sparrow. Zonotrichia lencoplirys gambeli. A migrant only, abundant on the Souris in fall migration (Coves). I have seen specimens taken at Carberry and at Portage la Prairie.

192. White-throated Sparrow. Zonotrichia albicollis. Common summer resident of all the wooded country Arrives early in May; departs late in October.

19:3. Tree-ensrrow. Spizella monticola. Abundant mito $n$. $\quad 2 \mathrm{ll}$ parts of the Province from mid-April

$$
\text { .y, and again through October. }
$$
resident sparrow. Spizella passirin. Summer apparently corded from corded fron 1 Pembina, IInnipeg, Norway House, Ou'Ard House, Grand Rapids, Prince Albert, and Prairie alle, as well as Carberry and Portage la tember. Not common; mid-April to late Sep19:. Clay-colored Sparrow. Spizella pallida. Very
abundant summer resident of the Alleghanian re-
gion. Arrives gion. Arrives May 1:); departs October 1.

196. Slate-colored Junco. Junio hyemalis. Abundant migrant throughout the Province, and doubtless breeding is all the Canadian region, though there are few records of it. Arrives the first week of April, and departs in October. 
:3is

\section{FAUNA OF MANITOB.I}

197. Montana Junco. Itinco hyemulis montanus. Imon:the migrant flocks of the preceding I have severi:l times seen this race near Carberry; one or two were collected.

19S. Song Sparrow. Melospiza melalia. Summer resident throughout the Prorince. Not common. Arrives late in April; departs carly in October.

199. Lincoln Sparrow. Mclos, liniolni. Spring and fall migrant. Noted during ist week of May and last week of September. Probably breeding in the extreme north-eastern part of the Province.

200. Swamp Sparrow. Melospiaa georgiana. Common summer resident throughout the Province, but most abundant in the Alleghanian region.

(0). Fox Sparrow. Passerella iliaci. Common migrant in the prairie region, arriving in mid-April. Breeding abundantly on Duck Mountain and apparently in all the Canidian region of the Provines.

(1)2. Townee. Pipilo erythropthalmus. Common summer resident of the Allegharian region north it least to Carberry; not yet recorded beyonc.

203. Arctic Towhee. Pipilo maculatus arcticus. This Western species appears in tinis list on the strength of a specimen taken on the Souris at the boundary, September 11, 187:3, by Dr. Elliot Coues.

0). Rose-breasted Grosbeak. Zameluiia ludovicianı. Common summer resident of the Alleghani? a region. possibly farther, as there is one record for the north end of lake Winnipeg.

20:. Indigo Bunting. Passerina cyanea. A male adult Indigo Bunting (No. 2,531 Seton Coll.) was killed on June $3,18(9)$, by W. R. Hine, near St. Boniface. between the Seine and Assiniboine Rivers, on the 
land between the Bishops's Marsh and the River Seine. Another adult male was taken at Estevan, South Saskatchewan, by I). I. Thorpe, 2!) May, 189:2. Estevan is eighty miles west of Manitoba. In the collection of Father Blain, St. Boniface College, is an extratordinary specimen killed at Winnipeg. After careful examination E. A. Preble and $I$ agree that it is probably a hybriol Indigo Bunting $X$ Common Canary, maybe escaped from captivity. With the general furm and color of an Indigo Bunting femule, it has some patches of yellow, and a white tail and wings.

206. Dickcissel or Black-throated Bunting. Spiza amiricana. August 10, 1899, I was shown an aclutt specimen of this bird by G. E. Atkinson, who shot it at Portage la Prairie, June 1,1897 . This was recorded in "Man. Free Press," March 5, 1!10 t.

207. Scarlet Tanager. Piranga erythromelas. I have seen two specimens that were taken at Vinnipeg in 189:2, one in the collection of George Grieve, the other in the collection of $W$. $R$. Hine. He also took another, and saw a third in 185s. It was about the end of May, during a sudden coll spell. The third he saw on the bank of Red River in the city limits; he was within two yards of it for some time, but did not collect it.

R. H. Hunter writes me that in June, 1850 , while camping cast of Winnipeg, he observed a pair, evidently nesting, and adds that his companion, Clementi-Smith, has "seen several pairs on the shores of Lake Winnipeg." "Lake Winnipeg" (Ridgü'ay). "Rare at Qu'Appelle" : juerisey).

_os. Purple Martin. Progne subis. Common summer resifent of all the Alleghanian region wherever there is large tim:ber to furnish nesting sites; also in towns. 
209. Cliff Swallow. Petrochelidon lunifrons. Abundant summer resident in all paits of the Province where cliffs or tall buildings in quiet places furnish nesting sites. Arrives May 15; departs August 30.

210. Barn Swallow. Hirundo erythrogastra. A summer resident of erratic distribution. Seldom seen about Winnipeg, not recorded from Portage la Prairie, and yet in $190+\mathrm{J}$. S. Charleson the taxidermist told me it was common at MacDonald and at Brandon. There is quite a colony at the former place under the long bridge. At Curberry I saw one or two each year; they arrived in the first half of May. Thus there are many records to show that, though rare, it is of general distribution, and further, it is increasing with the advance of settleinent. Near Wawanesa, on September 13, 1904, I saw a long straggling flock of nearly a hundred of the species flyn's south-west; many were within three or four feet of me as I drove.

211. Tree Swallow. Tridoprocne bicolur. Abundant summer resident in all parts of the Province where there are large trees.

212. Bank Swallow, Sand Martin. Ripuric ripuria. Common summer resident wherever it can tind suitable banks for nesting. Arrives mid-May; departs late in August.

21: Saw-winged Swallow. Stelgidopteryx serripennis. In the Manitoba Museun is a specimen of this Swallow, taken at Winnipeg by W. R. Hine.

214. Bohemian Wax-wing. Bombycilla garrula. A common winter visitant in most parts of Manitoba; often seen in November and April. Not known to nest here.

215. Cedar Wax-wing, Cherry Bird. Bombycillı cedro- 
rum. Abundant summer resiclent throughout the Province. Arrives late in May.

216. Northern Shr: 'ee. Lunius borealis. Common spring and fal! visitan', passing through toward the north in the first half of. pril, returning luring October.

217. White-rumped Shrike. Lanius ludovicicilus excubitorides. Abun lant summer resident throughout the Alleghanian regions. Arrives early in May; departs late in September.

218. Red-eyed Vireo. Vireusylua olivacea. Abundant summer resident wherever there is cover in all parts of the Province. Arrives May 24; departs late in August.

219. Philadelphia Vireo. Vireosylva philadelphica. A regular summer resident, not abundant, but probably in the woodlands throughout the Province. I found the nest and eggs near Fort Pelly (north-west of Duck Mountain), June 9, 188t. (See Auk, July, 1S55, p1. 305, 306.)

220. Warbling Vireo. Vireosylva gilva. Common summer resident of the Alleghanian region. Arrives Nay 30.

221. Yellow-throated Vireo. Lanivireo flavifrons. This species has not yet been taken in Manitoba, so far as I know, but being an Eastern species taken at Yorktown, Sask., by W. Raine, and at Moosejaw by Miller Christy, it is included as probable. II $R$. Hine claims to hareseen it on the Red River.

2.2.2. Blue-headed Vireo. Lanivireo soliturius. Sunmer resident in all parts of Manitoba: not common. Arrives about May 15 .

2.2:3. Black and White Warbler. Mniotilta varia. Summer resident in all the wooded parts of the Province; 
apparently most numerous in the spruce forests of the Canadian region. Arrives about May 15; departs at the end of August.

2.24. Nashville Warbler. Helminthophila rubricapilla. Rare summer rusident. Noted at Aweme, Lake Manitoba, Duck Mountain, and along Red River.

2.25. Orange-crowned Warbler. Hcluninthophila celata. Common summcr residerit of all woodlanis, apparently throughout the Province. Arrives May 1:2; departs end of September.

2.2(i. Tennessee Warbler. Helminthophila peregrina. Summer resident, breeding in most woodlands, but not plentiful. Noted on Big Plain and Duck Mountain, and alongr Red River near Wimnipeg. At T'embina common in the spring migration (Couss). North shore of Jake Winnipeg (Kennicott). Aweme (Cridlle). Arrives in mid-May; departs at the end of Septenber.

2.7. Cape May Warbler. Dendioica tigrina. Abundant migrant along Rerl River and a conimon summer resident in some regions, bu erratic in distribution. Recorded from Winnipeg. Shoal Lake, and Mrose Factory. Migrates in mid-May and late August.

-2s. Yellow Warbler. Iendroica aestiva. Very abundant summier resident of all thickets and woods throughout the l'rovince. Arrives May 1j; departs September 7 .

2.29) Myrtle Warbler. Dendroica coronati. Abundant migrant throughout the Province, breeding in the Canadian region. Arrives April 23; departs September 12.

2:30. Magnolia Warbler. Dendroica magnolic. Note1 only as a migrint, but doubtless breeds in the Canadian region. Arrives mirl-May: departs early September. 
2:31. Chestnut-sided Warbler. Dendroica ponns:liinica. Common summer resirlent in woorllands of tine Alle. ghanian region. Arrives about May ?0.

2:32. Bay-breasted Warbler. Deidroica castanea. A regule r migrant, especially along Red River; not common. Probably breeds in the northernmost part of the Province. Arrives mid-May.

2:3i3. Black-poll Warbler. Dendroica striata. Noterl orily as a migrant; not plentiful. Irrives at Aweme about May-13.

2:34. Black-throated Green Warbler. Diadroica virens. Norman Criddle reports this at Aweine on May 1:3 and $17,1898$.

23.). Blackburnian Warbler. Dendroica blakiburniae. A rare migrant in the Alleghanian region, probably breeding in the Canadian. Arrives late May.

2:36. Pine Warbler. Dendroica arigorsi. 1 rare summer resident in the evergreen forests of Srouth-castern Manitoba. "Arrives a!out Mat 10 ; departs about September 2" (Criddle).

237. Palm Warbler. Dendioica palmarumi. A common spring and lall migrant in the Alleghanian region; may breed in the Canarlian. Passes about the first week of Mity, and again about September lis.

2:3s. Ovenbird. Seiurus aturocapillus. Common summer resident of woodlands; apparently found throughout the Province. Arrives in mill-May; departs in mirl-September.

2:39. Water-thrush. Seiurus noveboraconsis notabilis. Conmon summer resident of all woodlands where there is water. Arrives in mid-May; departs late in September.

240. Connecticut Warbler. Oporornis azilis. Somewhat common summe: resident from mid-llay to early 


\section{FAUNA OF M.NitoBa}

September. Noted on Duck Mcuntain, Big Mlain, and along Red River. Nest fuund June 21, 1883. (See Auk, April, 1884, 1p. 192, 1933.)

$2+1$. Mourning Warbler. Opurornis philadelphia. Common summer resident of dry scrub lands throughout the Alleghanian region, arriving in late May, "departing early in September" (Criddle).

242. Northern Yellowthroat. Geothylpis trichus. Common summer resident of thickets in the Alleghanian region, arriving about May ?0), dejarting in September.

34:3. Wilson War iler. Wilsonia pusillı. Summer resident throughout the Province: not common. Arriving i: mid-Nay, departing in mid-September.

24t. Canadian Warbler. Wilsoniu canudensis. Apparently found throughout the Province as a rare summer resident. According to $N$. Criddle it arrives about May 20 and departs the last of August.

2.4.5. American Redstart. Setophaga ruticilia. Common sumner resident of all woodlands Arrives in midMay; departs in mirl-September.

246. American Pipit. Anthus ruhecens. Abundant spring and fall migrant throughout the Province.

247. Sprague Pipit., Missouri Skylark Anthus spraguei. Formerly resident summer of Assiniboine region wherever there were high dry' prairies, arriving May 1, departing September 1. This bird was very abundant on the Big Plain in 1882, but in 1892 I failed to see or hear a single individual in the country. It appears to have totally disappeared. This is unquestionably owing to the breaking up of the virgin prairie.

248. Catbird. Dumetellu curolmensis. Abundant sum- 
iner resident of the Alleghanian region. Arrives in mid-May; departs mid-September.

249. Brown Thrasher. Toxostoma rufum. Common summer resident of the Alleghanian region whereve: there are open woodlands. Arrives May 15; departs September 7 .

2i)0. Western House Wren. Troglodytes aedon parkmani. Abundant suinmer resident, appirently confined to the Alleghanian region. Arrives May 20; departs about the end of September.

251. Winter Wren. Nammus hicmalis. This is at woodland species, apparently common ir the southcastern quarter of the Povinee only. R. $H$. Hunter found it a common summer resident in the wo ds east of Winnipeg. C. W. Nash saw one at Winnipeg. and another at Portage lat Prairic. N. Criddle found it at Aweme.

252. Short-billed Marsh-wren. Cistothorus stelluris. Summer resident of the Alleghanian region; erratic in distribution. Preble found it at Norway House. Arrives May 15; departs Sept. 15.

253. Long-billed Marsh-wren. Telmatodytes palustris iliacus. Summer resident; of extensive, though erratic, distribution. Common at Winnipeg, Shoal I.ake, and Portage la Prairic. Recorded at Oak Point, Aweme, Waterhen River, and on Saskatchewan. Arrives early in May

254. Brown Crteper. Corthia familiaris americana. A rare summer resident. Noted at Winnipeg and Portage la Prairie, and Riding Mountain.

25).). Slender-billed Nuthatch. Sutta carolinensis aculeata. Somewhat rare resident of the heavily timbered regions. Absent from the Province only diring the hardest part of the winter. 
25). Red-breasted Nuthatch. Sittı canadensis. Rare summer resilent of the woorls in all parts of the l'rovince; abundant during the inigration in September.

257. Long-tailed Chickadee. Penthestes atricapillus septentrionalis. Resident; abundant in all the woorllands. The Manitoba bird is not strictly septentrio. nalis, but is nearer to that form than to atric. pillus.

2is. Hudsonian Chickadee. Penthestes hudsonicus. The only record is is follows:--"In flocks around the Purcupine Mountains" (Macoun). The bird is certainly not found in the Assinitioine region, and there are no Red River records, though it should be the prevailing species in the Winnipeg Basin.

"i)!. Golden-crowned Kinglet. Regulus satrapa. Rarc migrant. Noted at Carberry, November i), 188. and recordel also from Aweme, Portage lat P'rairic. and llinnipeg.

2(i). Ruby-crowned Kinglet. Regulus calendula. Common migrant. Noted on Big Plain about May 1j). along Red River, and at Portage la Prairie. "On Souris in September" (Coues). Probably breeds in the north-east part of the Province. Passes through in late April and early Mlay; again about the 1st of October.

2(i). Willow Veery. Hylocichla fusiescens salpicola. Abundant summer resident of all thickets in the Alleghanian region. Arrives in mid-May; departs early in September.

2(i). Gray-cheeked Thrush. Hyloci.hli aliciue. Common migrant. Imperfectly observed. as it is not usually distingrished from the next.

2(ii). Olive-backed Thrush. Hylocichla ustulata sioninsoni. Common summer resident of woodlands 
apparently throughout the Province. Arriv... May 1; departs carly in October.

2(it. Hermit Thrush. Iylocichla gultala pallasi. Common summer resident of woollands in the Canadian region. I migrant in the Alleghanian, passing in late April and carly October.

2(i). American Robin. Plancsticus migratorius. Ibunciant summer resident throughout the Province. Arrives April 15); departs October 1.j.

2(iti. Bluebird. Sialia sialis. Formerly very rare; has become quite a regular summer resident in the country along the Assiniboine, and nearly erery. grove of oak of any extent is found to have al pait making their home in it along with the l'urple Martins.

2(is. Mountain Bluebird. Sialia currucoides. F. H. Patterson secured one of a pair that he found at a place two miles west of Brandon, and sent the same to G. E. Athinson, who recorded it in "Man. Free Press," March 5, 1904. To this, Norman Criddle (the naturalist responsible for records irom diveme) adds ("Ottawa Naturalist," July, 1904, pl) S.), s(i) that the species is by no means uncommon about the Carberry sandhills, and that he has taken numerous nests there. 


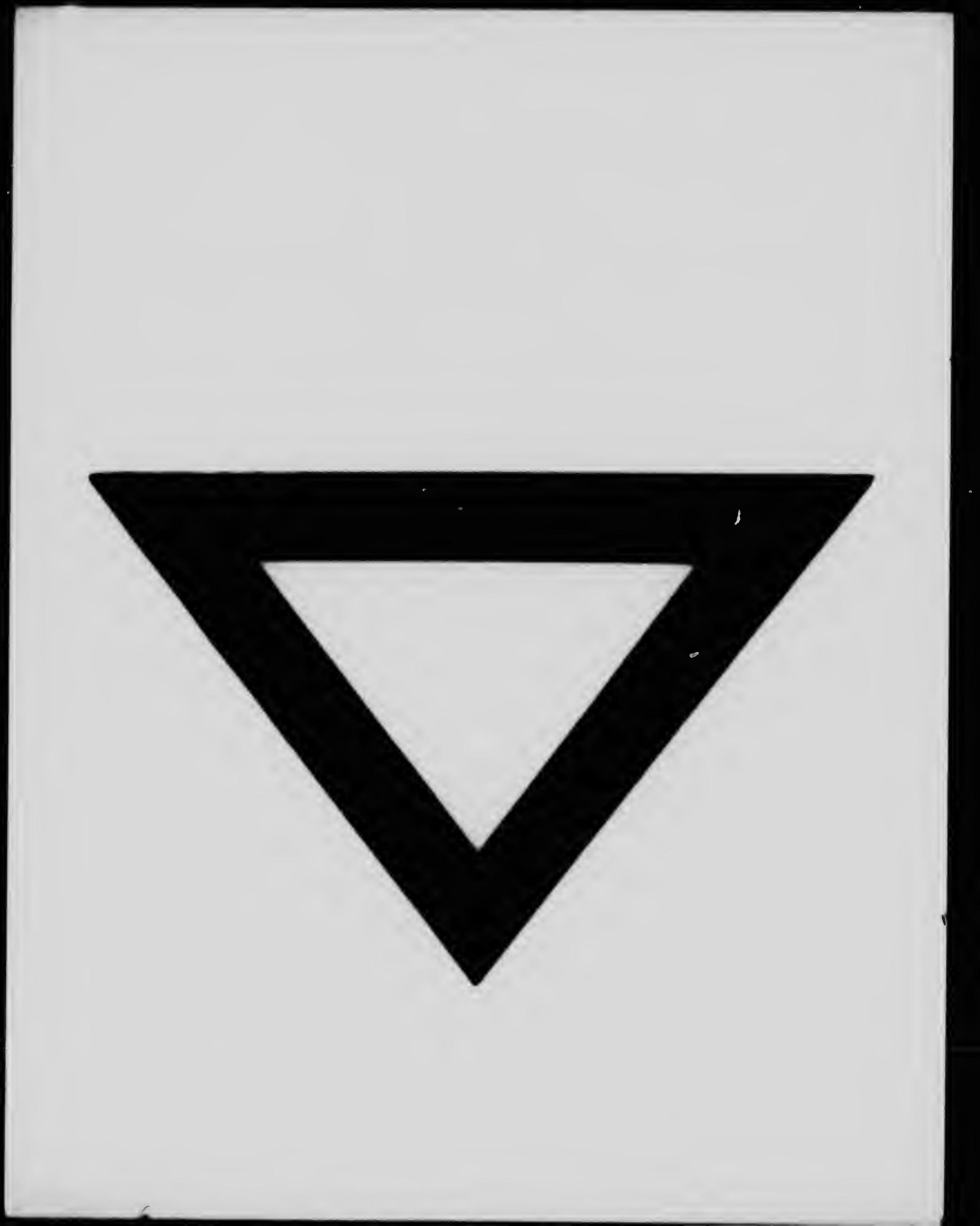

